\title{
The Application of X.Class Teacher Program to Enhance Students' Listening and Speaking Skills in Al Baha University
}

\author{
Elsadig Mohamed Khalifa Gawi \\ College of Arts and science-Almandaq, Al Baha University, Saudi Arabia \\ E-mail: sadig_99@yahoo.com
}

$\begin{array}{lll}\text { Received: 05-02- } 2015 & \text { Accepted: 16-04- 2015 } & \text { Advance Access Published: May 2015 } \\ \text { Published: 01-09- 2015 } & \text { doi:10.7575/aiac.ijalel.v.4n.5p.154 } & \text { URL: http://dx.doi.org/10.7575/aiac.ijalel.v.4n.5p.154 }\end{array}$

\begin{abstract}
The present study focuses on the implementation of technological aids in improving foreign language education by investigating the impact of using X. Class Teacher's Program on teaching listening and speaking skills of Al Baha University Students. It aims at improving students' listening and speaking skills through the use of the above mentioned program. A multi-method approach will be adopted to enable researchers to extract information from different perspectives. This approach will involve tests and classroom practice and observation. The participants of the study will be a sample of students from the recently enrolled beginners in listening and speaking skills courses in the College of Arts and Science in Almandaq. SPSS mechanism will be used to analyze the data to verify the hypothesis that X. Class Teacher helps in improving students listening and speaking skills. The study recommended that X.Class Teacher Program is the best way to develop listening and speaking skills.
\end{abstract}

Keywords: X.Class Teacher Program, software, technological aid

\section{Introduction}

The world has recently witnessed great care in the implementation of technological aids in every walk of life, with special care in improving foreign language education in listening and speaking skills in particular. By the end of this training program we except students to be able to do the following with the learning of these skills of listening and speaking:

1. Students are expected to use these skills in their daily routine in asking and requesting a service, suggesting an idea or giving instructions to others in a direct contact or by making a telephone call or talking to receptionist or people expected to offer special service.

2. To use these skills to understand a lecture on a theatre or listening to a speaker on the radio or TV. Program.

3. To use these skills in the academic field such as asking about an idea or exchanging points of views with teachers or colleagues or explaining a situation.

4. To use skills in travelling abroad and be able to interact with people in airports, hotels, restaurants, banks, taxi drivers etc. as well as asking about places and directions in the foreign country.

5. To be able to describe people, geographical places and to explain health condition and personal moods.

6. To express his likes and dislikes -show agreement or disagreement- accept or refuse suggestions-to express plans and use the right time to talk about events in the past, present and future.

\section{Literature review}

A thorough review of language teaching practices will be done covering the local and international modern trends in language education. The study will focus on the Saudi teaching experiences through the long history of teaching English in this country, A first hand data will be collected as well as the collecting data from different secondary recourses and references, from the international linguistic community. A review of language teaching practices will be investigated and comments will add to the rich literature of foreign language teaching. A special chapter will focus on the practices of language instructors in teaching the listening and speaking skills in particular. The environment in teaching such skills is very important so a thorough investigation will be made through questionnaires, interviews and observations of the teaching force in the field.

\subsection{Listening skills}

Listening is considered as very important skills in our everyday activities. It is one of the most important aspects of communication process. Listening skills help learners to understand and read the other person's message. 
According to Thompson (1995) "listening is a process of receiving constructing meaning form and responding to spoken and/or nonverbal message".

By practice listening, students will maintain the skills they have and develop new ones. To develop effective listening skills, learners need to practice to obtain the skill.

A skill according to Merriam-Webster online dictionary is a learned power of doing something competently: a developed aptitude or ability. The listening skill is a skill that everyone should have but most people lack. It is not merely the act of hearing a sound but of paying attention to what someone is saying and understanding a message. The distinctive between hearing and listening can be ambiguous. Hearing is a physical action while listening is both physical and psychological. If you are a good listener, it will help you in your study, work, making relationship, and in other situations.

\subsection{Listening in the classroom}

Listening is one of the most powerful tools of communication and is a process that is used to receive, convey a meaning, and respond to both verbal and nonverbal messages. It requires more work than speaking. The effective listening in the classroom consists of various communication activities such as listening, speaking, making questions, participating in pair and group works. In addition, listening skill is one of the most important aspects of communication process. Effective listening skills help in developing other learning skills. It helps to understand, speak, read, and write.

Listening in the classroom is the main way of communicating knowledge in that educational setting, so to be able to listen effectively is very important to success in developing the language skills. There are many different techniques if students follow, practice, and master, can lead them to success. The first step to develop listening skills in the classroom is to be prepared. Organizing the language lab in a calm place, asking students to read the chapter being covered or rereading notes it is easier to listen. Because the content is not being introduced for the first time, it is easier to comprehend it.

\subsection{The previous studies}

Mu-hsuan Chou (2015) writes a research paper about the influence of listening strategies use for English for academic purposes. It aims at investigating what strategies were adopted to listen to general and subject specific English materials. This study examines the process of listening comprehension in relation to effectiveness of strategy use. The participants were 92 Taiwanese final-year university students taking EAP courses. The findings showed that strategy use varied markedly between the two types of listening materials. The effectiveness of certain listening strategy adoption was influenced by topical familiarity and personal experience.

Nguyen V. and Henritte V. (2014) presented a research paper about the effect of Computer Assisted Language Learning (CALL) on performance in the Test of English for International Communication (TOEIC) listening module. The participants of this study were 25 Vietnamese students who attended TOEIC listening class after dividing them into two groups. The material input was designed with the application of the computer assisted language learning program introduced in the treatment group only whereas the control group still learned with the current textbook only. The findings showed that there was difference in the performance on TOEIC listening test scores between two groups. The students in the treatment group used listening strategies more effectively than the students in the control group. Using of the Computer Assisted Language Learning instruction and teaching method increased the students' TOEIC listening scores significantly.

Yin X (2015) investigates the development of English listening for non-English majors in China. A discourse-oriented approach has been introduced into the listening classroom. Some theories in discourse analysis such as cohesion, coherence, schema, and relevance are critically important in enhancing the students' listening comprehension ability and improving their communicative competence. This study considers the correlation between the theories of discourse analysis and the nature of listening comprehension and the developmental differences in the learners' listening proficiency brought from the discourse approach. Through the analysis of listening difficulties and experiment the results confirmed the effectiveness of the discourse-oriented approach. It suggested an uncomplicated procedure that might have considerable and varied payoff in terms of listening teaching and learning.

In addition, Lee (2008: 84) implemented a study that investigated how Taiwanese students' learning English pronunciation is assisted by two software programs. 153 college students joined this research and they were supposed to use two computer software programs and answer 6 open ended questions, for example,

(1) What are the characteristics of this program?

(2) What are the advantages of this program?

(3) What kind of improvement does it need to meet your needs?

(4) What are the differences between a real teacher and this program?

The results indicated that the students found two programs interesting and helpful for them. However, they liked the one with 'explicit correction feedback, and with repetition and other specific functions, as well as the facility for self-paced and self-directed learning' (Lee, 2008: 2).

Lin (2004, cited in Levy, 2006) carried out a study to investigate how learners' incidental vocabulary is improved by video-based Computer Assisted Language Learning. In that research, after using an English proficiency test, eighty two university freshmen were divided into three groups: 
(a) High reading and high listening English proficiency.

(b) High reading and low listening English proficiency.

(c) Low reading and high listening English proficiency.

All members in three groups underwent five vocabulary follow-up tests, five English video-based lessons were chosen from the $2006 \mathrm{CNN}$ news and vocabulary pre-test and post-test. It required eight periods for data collection to come to the final findings. Lin (2004, cited in Levy, 2006) found out all three group's post-test vocabulary were higher than those of their pre-test. In other words, learners' vocabulary can be facilitated and promoted through video-based CALL activities.

\section{Methodology}

A multi-method approach will be adopted to enable the researcher to extract information from different perspectives. This approach will involve tests and classroom practice and observation.

\subsection{The population of the study}

The population of the study will be the community of students who are taking the listening and speaking course in AlBaha University. The sampling is going to be a random selection targeting a group of people around (20) students to be named as a pilot group and another group of (20) students to be named as a control group.

\subsection{Tools of data collection}

The researcher runs a pretest to measure the students' performance learning listening and speaking skills through the use of traditional stereo speakers. Interaction (2) represented the target syllabus taught that English in an integral way.

Before beginning the teaching through the X-Class Teacher Aids, the two groups are going to have a pre- listening and speaking test. Then the course will be taught and a post test is going to take place to the experimental group. The two results will be correlated to check if there is a significant difference before and after using the X-class teacher.

\subsection{Duration}

The course takes one semester. So the experimental group will be exposed to teaching for (15) weeks then be examined to see the final results of our teaching.

\subsection{Research devices:}

This experiment presupposes the set-up of an X-Class Language Lab and a well-trained teacher to professionally carry the experiment. Other data can be extracted through interviews, questionnaires, observations and tests to support the validity and reliability of this experiment.

\subsection{Data analysis}

The participants of this study had taken pre-test and post-test. SPSS software was used to calculate the t-test, means and standard deviation to verify the hypothesis that X. Class Teacher helps in improving students listening and speaking skills.

\section{Data Analysis, Results, and Discussion}

\subsection{Analysis of pre-test}

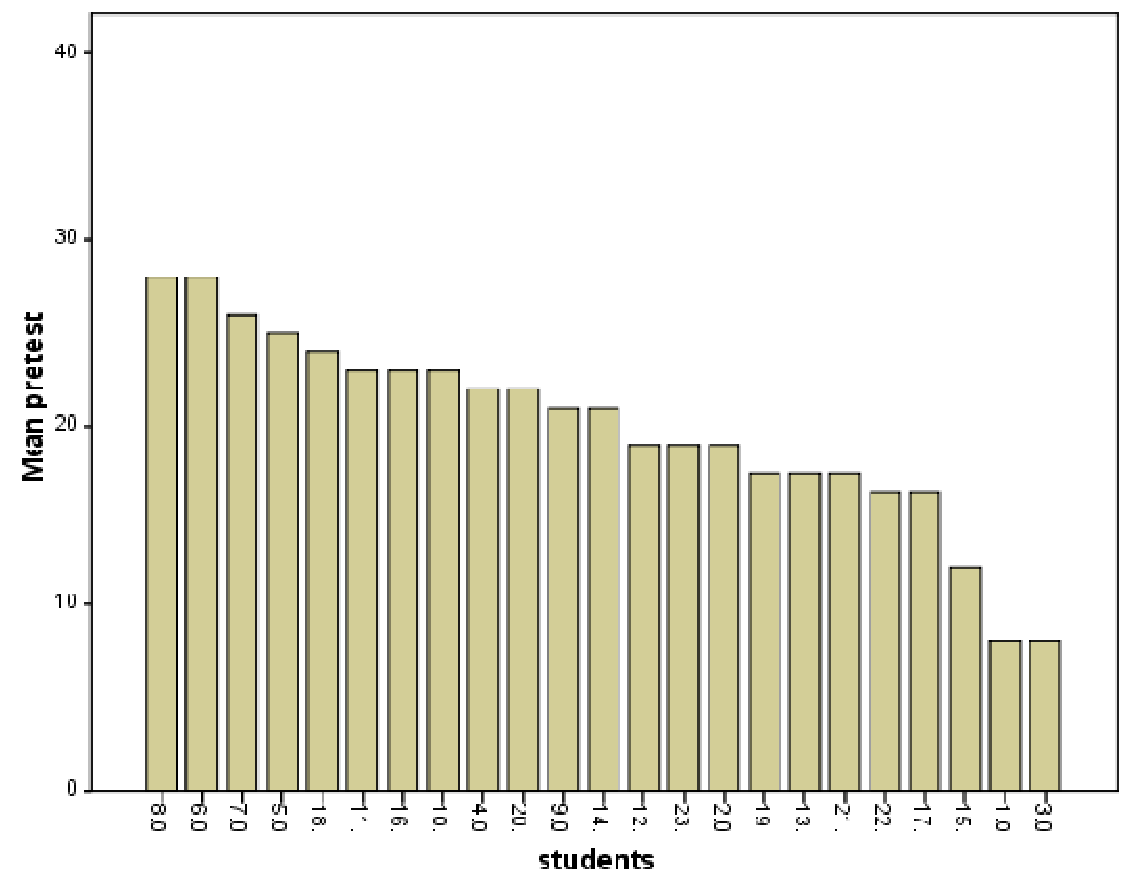

Figure 1. Summary of the students means in the listening pre-test played by stereo speaker recorder 
Figure 1 shows the performance of the students in a pre-test involving listening and speaking skills. In general, nearly $50 \%$ of the students' scores range below the pass the mark, whereas $50 \%$ of scores range between 1 to 30 marks. The results suggest that students have relatively low scores. Several possible interpretations for this performance can be discussed. Firstly, the use of a traditional recording apparatus (stereo speakers/ recorders) that is equipped with a recorder and loud speakers can influence the performance of our students. The loud speakers allow students to hear conversations; however, they often lack clarity which results in intelligibility degradation. Secondly, listening tasks manipulated by loud speakers are sometimes vulnerable to confusions resulting from the surrounding noise. These factors combined probably lead to the low performance of the students in such a test. Therefore, the use of a more advanced language laboratory with appropriate components is needed to upgrade learners' performance.

\subsection{Analysis of pre-test and post-test}

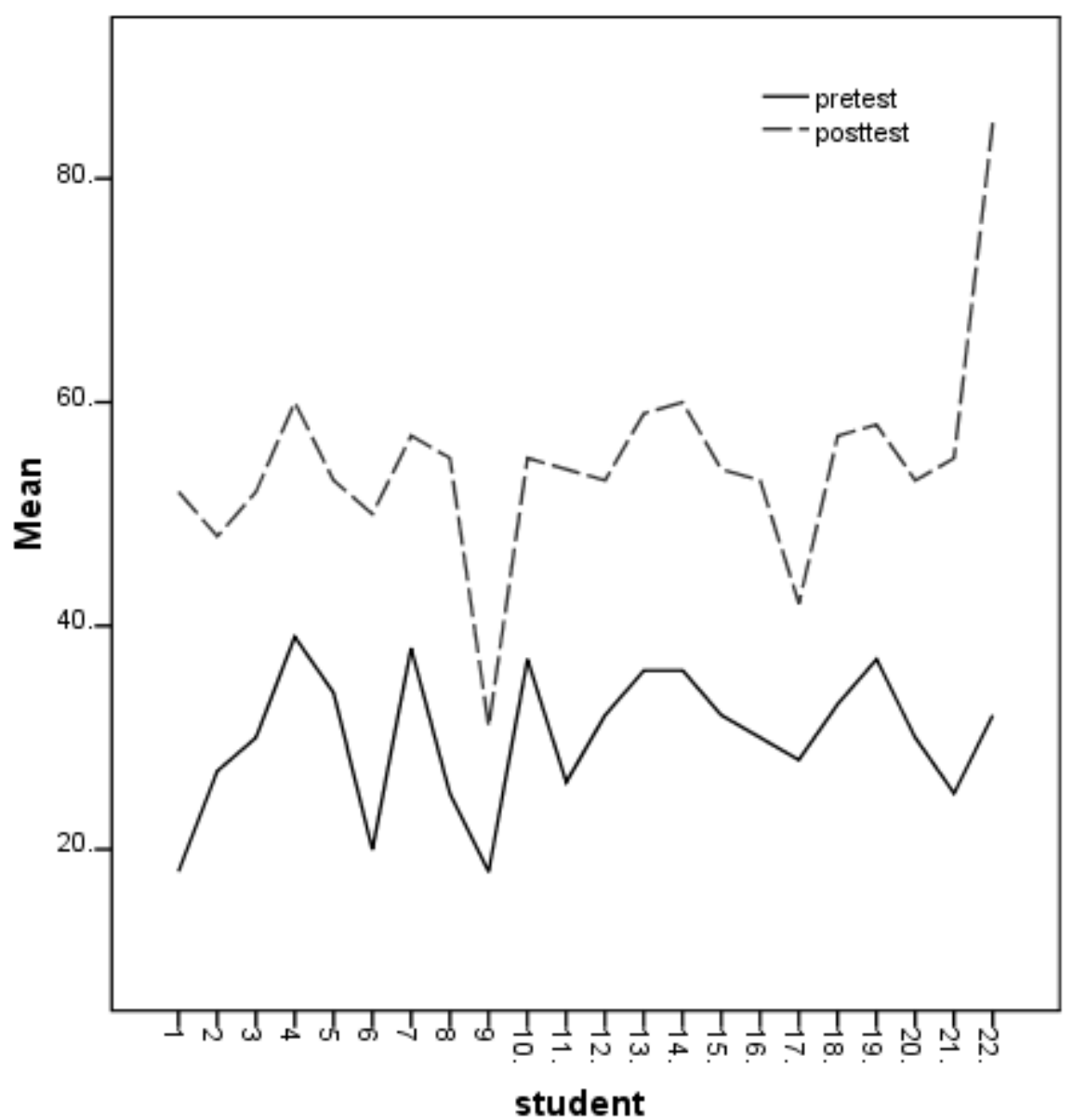

Figure 2. total mean of the performance of the students in pre-test and posttest in post-tests

Results in figure (2) show the data are lined up in perfect parallel lines, which suggest that some correspondence arises between the two data. One possibility to describe these results is that students have reasonably higher scores in the post test when they are trained on X. Class Teacher Program than when they are trained on normal recording apparatus. There is a statistically significant difference between the two data where the correlation is $(\mathrm{r}=.503$ p.05). Discussion of this data will take place in the discussion section.

\subsection{Discussion}

The results of the pre-test (fig.1) show that the students' performance is very weak in listening and speaking skills before exposing to the $\mathrm{X}$. Class teacher program.

The analysis of the data, in figure 2 above, shows that there is a statistically significant difference between the results of pre-test and post-test where the correlation is $(\mathrm{r}=.503 \mathrm{p} .05)$. This means that the performance of the students is developed after exposing to the X-Class teacher program in their study.

With the increasing of the importance of English language in Saudi universities, listening skills have become essential for EFL learners to manage their study in different subjects. The findings of the pre-test suggest that students have relatively low scores (fig. 1). This show that Saudi students' performance is very weak in listening and speaking skills using the traditional method in teaching listening and speaking skills.

After the students were exposing to X-Class teacher program, the findings shows that figure 2), there is a statistically significant difference between the results of pre-test and post-test where the correlation is $(\mathrm{r}=.503 \mathrm{p} .05)$. This means that the performance of the students is developed after exposing to the X-Class teacher program in their study. 


\section{Conclusions}

A number of studies have shown the advantage of using software materials in class to facilitate students' listening skills in the lab setting (Lynch, 2011) and (Kashani et al, 2011). In addition; Coyle (2010) and Rost (2011) suggest that learning of and through the target language should take place in an environment that provides learners with comprehensive inputs.

The present study was carried out with 40 Saudi university students ( $3^{\text {rd }}$ level) learning listening and speaking course through XClass Teacher program in the College of Arts and Sciences in Almandaq, Al Baha University, in the first term $1435 / 1436$.

The results of this study show that XClass Teacher program has great effect on developing students' listening and speaking skills. It is clear that the performance of students was developed after exposing to the program mentioned above.

\subsection{Recommendations}

1. This research is considered as a pioneer study in the situation of the developing students' listening and speaking skills through using technology. In order to check if resemble results will happen, similar studies can be done in the other colleges specially the girls ones.

2. The researcher recommended that using XClass teacher program is the best way to develop students' listening and speaking skills.

3. The present study deals with male students. However, it can be extended to include female students in Al Baha University.

4. Most of the Arts colleges lack languages labs and software program, so University Directorate should prepare language laboratories supported with X-Class teacher program and software.

\section{References}

Brod, S. (1996). Teaching Listening in the Workplace English language Training Program at the Spring Institute. Unpublished manuscript.

Brown, G \& Yule. G (1983). Teaching the Spoken Language, Cambridge: Cambridge University Press.

Brown, H.D. (1994). Teaching by principles: An interactive approach to language pedagogy. Englewood Cliffs, NJ: Prentice Hall Regents.

Coyle, D. \& Marsh, D. (2010). Content and language integrated learning. Cambridge, UK: Cambridge University Press.

Dunkel, P. (1986): Developing listening fluency in L2: Theoretical principles and pedagogical considerations. The Modern Language Journal, 70(2), 99-106.

Dunkel, P. (1991). Listening in the native and second/foreign language: Toward an integration of research and practice. TESOL Quarterly, 25(3), 431-457.

Kashani, A. et al (2011): Optimizing visually-assisted listening comprehension. Language Learning Journal, 39(1), 75 84.

Lee, S. T. (2008). Teaching Pronunciation of English Using Computer Assisted Learning Software: An Action Research Study in an Institute of Technology in Taiwan (Unpublished doctoral dissertation, Institute of Technology in Taiwan, Taipai, Taiwan).

Levy, M. (2006). CALL Dimensions: Options and issues in computer-assisted language learning. New Jersey: Lawrence Erlbaum Associates.

Lund, R.J. (1990). A taxonomy for teaching second language listening. Foreign Language Annals, 23, 105-115.

Lynch, T. (2011). Academic listening in the 21st century: Reviewing a decade of research. Journal of English for Academic Purposes, 10(2), 79-88. 2011.03.001

Mendelsohn, D.J. (1994): Learning to listen: A strategy-based approach for the second-language learner. San Diego: Dominie Press.

Morley, J. (1991): Listening comprehension in second/foreign language instruction. In M. Celce- Mu-husan C. (2015): The Influence of Topics on Listening Strategy Use for English for Academic Purposes. English language Teaching, $8(2)$.

Murcia (Ed.), Teaching English as a second or foreign language (2nd ed.) (pp. 81-106). Boston: Heinle and Heinle. Study Circle on Teaching Listening, Speaking, and Pronunciation IV-D-63Participant Handouts The CAELA Guide for Adult ESL Trainers

Nguyen V. et al (2014) The Effect of Computer Assisted Language Learning (CALL) on Performance in the Test of English for International Communication. 
Nunan, D., \& Miller, L. (1995): New Ways in Teaching Listening. Alexandria, VA: Teachers of English to Speakers of Other Languages.

Peterson, P.W. (1991): A synthesis of methods for interactive listening. In M. Celce-Murcia(Ed.),Teaching English as a second/foreign language (2nd ed.) (pp.106-122). Boston: Heinle and Heinle.

Richards, J. (1983). Listening comprehension: Approach, design, procedure. TESOL Quarterly, 17(2), 219-240.

Rivers, W.M. (1981). Teaching foreign language skills (2nd ed.). Chicago: University of Chicago Press.

Rost, M. (1991): Listening in action: Activities for developing listening in language teaching. New York: Prentice Hall.

Rubin, J. (1994): A review of second language listening comprehension research. The Modern Language Journal, 78(2), 199-221.

Rubin, J. (1995). The Contribution of Video to the Development of Competence in Listening. In D. Mendelsohn \& J. Rubin (Eds.), A guide for the teaching of second language listening(pp. 151-165). San Diego, Dominie Press.

Thompson I. (1995): Assessment of Second/foreign language listening comprehension. A guide for the teaching of listening Second language listening. San Diego, CA: Dominie Press.

Wolvin, A., \& Coakley, C. (1991): A survey of the status of listening training in some Fortune 500 Corporations. Communication Education, 40, 152-164.

Yinxiu J. (2015) Discourse Analysis and Development of English Listening for Non-English Majors in China.

\section{Appendices}

Appendix-1

Students' test

Student's Name

[1] Listen to the underlined words and phrases. Then, match them with their definitions:

\begin{tabular}{|c|c|}
\hline Sentences & Definitions \\
\hline $\begin{array}{l}\text { 1. I'm going to sign up for an exercise class at the gym. } \\
\text { ( })\end{array}$ & a. to succeed \\
\hline $\begin{array}{l}\text { 2. She's planning to major in art at the University of } \\
\text { Washington }\end{array}$ & b. to like/love \\
\hline $\begin{array}{l}\text { 3. I don't like classical music, but I am really into jazz. } \\
\text { ( } \quad \text { ) }\end{array}$ & $\begin{array}{l}\text { c. to specialize in a particular } \\
\text { subject/field }\end{array}$ \\
\hline $\begin{array}{l}\text { 4. You have to get a good education if you want to get ahead } \\
\text { in life. }\end{array}$ & d. to register/join \\
\hline $\begin{array}{l}\text { 5. She has a successful career as a fashion designer. } \\
\text { ( } \quad \text { ) }\end{array}$ & e. a profession/job \\
\hline
\end{tabular}

2. Listen to the conversation. Then, choose the correct answer:
1. a. a neighbor
b. the apartment manager
c. Donna's father
d. a repairman
2. a. repairperson
b. a painter
c. an exterminator
d. a plumber
3. a. It's on the third floor
b. It's in a bad condition
c. It's in a good neighborhood
d. It's cheap
4. a. He thinks it's very funny
b. He's surprised to see Donna
c. He's a little angry
d. He is happy to help Donna
5. a. He is happy to help Donna
b. He's surprised to see Donna
c. He's annoyed with Donna
d. He's very worried 


\section{Complete the following conversation, write the unreduced form:}

Customer: Hi, my name is Chang Lee.

Teller: How. I help you?

Customer: I Check my balance.

Teller: OK I have your account number, please?

Customer: 381335

Teller: Your balance is $\$ 201$

Customer: OK I My father wire me some money. I'd like

Know if it's arrived.

Teller: I'm sorry. Your account doesn't show any deposit.

Customer: Oh, no. I need pay my rent tomorrow.

think I do?

Teller: Well, we're having some computer problems today. So, why

Call us later to check again? Or come back. We're open till 5:00

Customer: OK, thanks.

Teller: You're welcome.

(4) Listen to the lecture. Then, complete the missing information:

Entrepreneurial process
a. Identify a problem.
b.
c.
d.

"End of questions" 